logos_i_ethos_2021_2_(58), s. 107-126

https://doi.org/10.15633/lie.4172

Marcin Tomasiewicz

https://orcid.org/0000-0003-2803-9364

Uniwersytet Papieski Jana Pawła II w Krakowie

\title{
Cykliczny i linearny obraz dziejów w historiozofii XX wieku na podstawie myśli Oswalda Spenglera i Francisa Fukuyamy
}

Chociaż filozofia dziejów jako dyscyplina filozoficzna wyodrębniła się czasach oświecenia, to jej początki zwykło się wiązać z PańMarcin Tomasiewicz, teolog i prawnik, doktor nauk prawnych. Doktorant na kierunku filozofia na Uniwersytecie Papieskim Jana Pawła II w Krakowie. stwem Bożym św. Augustyna. Pogląd ten, chociaż słuszny, stanowi pewne uproszczenie, ponieważ elementy historiozoficzne pojawiały się już w czasach wcześniejszych. Sam Augustyn, pisząc swoje dzieło, musiał zmierzyć się z refleksją wokół historii wypływającą ze środowisk inteligencji pogańskiej. W efekcie stworzył obraz dziejów, posiadających sens i cel, gdzie panorama wydarzeń historycznych została zamknięta pomiędzy początkiem a eschatologicznym końcem. Chociaż koncepcja Augustyna wspierała się na liniowym modelu historii, to linearność nie cechowała wszystkich chrześcijańskich historiozofii. Jeszcze w starożytności i średniowieczu koncepcje cyrkularne miały wpływ na teologię historii ${ }^{1}$.

W dobie krystalizacji filozofii dziejów, przypadającej na wiek XVIII, mamy do czynienia z triumfem linearnej wizji historii, połączonej z koncepcją kumulatywnego postępu. Wraz z narastającą od drugiej połowy XIX wieku krytyką oświeceniowego optymizmu owa postępowa wizja

1 Por. M. Eliade, Mit wiecznego powrotu, Warszawa 1998, s. 155n. 
traciła moc oddziaływania, by ostatecznie znów dopuścić do głosu nurty cyrkularne ${ }^{2}$.

Celem niniejszego artykułu jest zestawienie modelu cyklicznego i linearnego $w$ historiozofii XX wieku, $\mathrm{z}$ uwzględnieniem ich implikacji na polu doktryn politycznych. Zostanie tym samym podjęta próba potwierdzenia przekonania, że przyjęty model historiozoficzny wpływa na aprobatę określonych systemów politycznych bądź dezaprobatę wobec nich. Za materiał do badania posłużyły przykłady zaczerpnięte z myśli Oswalda Spenglera i Francisa Fukuyamy. Wybór akurat tych myślicieli nie był rzeczą prostą. Historiozofia XX wieku wypracowała niemałe bogactwo stanowisk i koncepcji w ramach zarówno liniowej, jak i cyrkularnej tradycji, zaś na całość tej literatury składają się prace autorów różnej orientacji filozoficznej. Zadanie wyłonienia dwóch stanowisk wymagało zatem solidnego namysłu. Na ostatecznym wyborze zaważyły następujące względy.

Po pierwsze - kryterium chronologiczne. Filozofia XX wieku jest bardzo niejednolita. Właściwie można wskazać wiele mód intelektualnych, założeń i kierunków, które często, poza stosunkowo niewielkim interwałem czasowym, dzieli prawie wszystko. Pojawia się pokusa, by mówić raczej o filozofiach dziejów pierwszej lub drugiej połowy XX wieku, przedwojennych lub powojennych, komunistycznych czy liberalnych. Jednak tak daleko idąca konkretyzacja nie jest w tym miejscu konieczna, a nawet okazuje się wręcz niemożliwa, gdyż historiozofie te bardzo często pozostawały ze sobą $\mathrm{w}$ relacjach polemicznych. Ukazanie ich obok siebie

2 Przeświadczenie o kompromitacji liniowej koncepcji dziejów, a także całej historiozofii na skutek rozczarowania optymistycznymi projektami dziejów w epoce oświecenia prezentuje Emil Angehrn. Zob. E. Angehrn, Filozofia dziejów, Kęty 2007, s. 3. Trzeba jednak zaznaczyć, że pogląd, jakoby idea kumulatywnego postępu była konceptem nowożytnym spotyka się z krytyką. Zob. R. Nisbet, Social Change and History. Aspects of Western Theory of Development, New York 1969, s. 41; Z. J. Czarnecki, Wartość i historia. Studia nad refleksja filozoficzną o ludzkim świecie, Lublin 1992, s. 44-46; Z.J. Czarnecki, Przyszłość i historia, Lublin 1981, s. 88-89. Szerzej o linearnej koncepcji w myśli starożytnych piszą: L. Edelstein, The Idea of Progress in Classical Antiquity, Baltimore 1967; R. Nisbet, History of The Idea of Progress, New York 1980; L. Sklair, The Sociology of Progress, London 1970. Na pluralizm stanowisk starożytnych w kwestii czasu zwraca uwagę Lloyd. Zob. G.E.R. Lloyd, Czas w myśli greckiej, w: Czas w kulturze, red. A. Zajączkowski, Warszawa 1988, s. 208. 
wymagałoby nie tyle przedstawienia konkretnego modelu dziejów, ile raczej pewnej dyskusji pomiędzy prezentowanymi autorami. Z tego też względu wydaje się stosowne brać pod uwagę filozofię XX wieku w ogóle, nie korzystając z żadnych dokładniejszych periodyzacji.

Po drugie - kryterium przedmiotowe, którym z konieczności być musi powiązanie myśli historiozoficznej z określoną wizją polityczną.

Wreszcie - wspólne źródło inspiracji omawianych autorów stwarza odpowiedni grunt do możliwości ich zestawienia. Zarówno Spengler, jak i Fukuyama pozostają w wyraźnej zależności względem heglizmu. Niemiecki badacz, chociaż sam jest dość skromny w wyznaniach odnośnie do intelektualnego długu względem jakiegokolwiek wcześniejszego filozofa, zdradza się jednak zamiłowaniem do dialektycznych zestawień, które charakteryzują właśnie heglizm. Nie bez znaczenia jest również fakt, że Spengler wyrósł z dziedzictwa niemieckiej filozofii, która pozostawała pod silnym wpływem Hegla (zwłaszcza w materii historiozofii). Jeśli zaś idzie o Francisa Fukuyamę, to wprost wyznaje on, iż jego filozofia w gruncie rzeczy wspiera się na heglizmie.

\section{Model cyrkularny}

Cykliczna teoria dziejów została zaprezentowana w dziele Zmierzch $\mathrm{Za-}$ chodu Oswalda Spenglera. Autor ów widział swoje zadanie w stworzeniu nowego modelu filozofii historii, opierając go na pojęciach charakteryzujących przyrodę ${ }^{3}$, a zatem w kategoriach wzrostu i obumierania żywych organizmów. Stąd też Zbigniew Kuderowicz klasyfikuje jego myśl jako katastrofizm naturalistyczny ${ }^{4}$.

Wywód Spenglera osnuty jest wokół dialektycznego zestawienia dwóch par pojęć: „istnienie bezwiedne” i „istnienie czuwające” oraz „kultura” i „cywilizacja”. $\mathrm{Z}$ nich zaś zasadniczy wydaje się podział

3 Zob. A. Kołakowski, Spengler, Warszawa 1981, s. 51.

4 Zob. Z. Kuderowicz, Filozofia dziejów, Warszawa 1983, s. 217.

5 Używane przeze mnie terminy ,istnienie bezwiedne” $\mathrm{i}$, istnienie czuwające” pochodzą z tłumaczenia dokonanego przez Andrzeja Kołakowskiego. 
na istnienie bezwiedne i istnienie czuwające, które w nowszym tłumaczeniu zostały oddane poprzez terminy: „istnienie nieprzytomne” i „byt

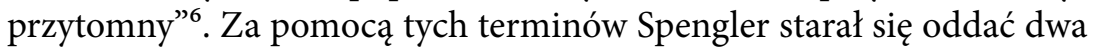
sposoby bytowania, czy też dwa stopnie bytu ${ }^{7}$. Najlepiej można uchwycić ich sens poprzez odniesienie do biologii. W Zmierzchu Zachodu czytamy: „Roślina jest czymś kosmicznym, zwierzę jest prócz tego mikrokosmosem w relacji do makrokosmosu. Wszystko «kosmiczne» nosi cechę periodyczności. Ma takt kosmiczny. Wszystko «mikrokosmiczne» cechuje biegunowość. Istotę tego wyraża słowo «wobec». Ma też napięcie. (...) Roślina wiedzie istnienie nieprzytomne (nierozbudzone). Istnienie to ma takt i kierunek. Zwierzę natomiast jest ponadto przytomne (rozbudzone). Byt przytomny jest napięciem i rozciągłością. Człowiek to przede wszystkim byt przytomny"8.

Istnienie nieprzytomne (bezwiedne) posiada wewnętrzną jednolitość, cechuje je rytm, pęd, kierunek oraz los i przeznaczenie. Brakuje mu natomiast elementu samoświadomości. Z kolei istnienie przytomne (czuwające) wiąże się z napięciem, biegunowością, rozciągłością. Można rzec, że jego konstrukcja jest dwoista, a opozycyjne człony ujawniają pewne napięcie. Istnienie to jest ponadto wyposażone $\mathrm{w}$ nadbudowę świadomości. Spengler określił to pierwsze jako „życie”, w odniesieniu do drugiego tylko raz użył terminu „świadomość”" . Oba są ulepszoną wersją bycia i stawania się. Nie da się ich odnaleźć w stanie czystym. Wszystkie określenia odniesione do istnienia bezwiednego, rozumianego jako „życie”, kierują nas do cech i wartości biologicznych, nieświadomych, wolicjonalnych, rządzonych igraszką przeznaczenia i przypadku. Życie narzuca się im i je determinuje. Istotnym elementem owego życia jest rytmiczne pulsowanie i trwanie wewnątrz cykli. Dynamizm ten jest również obecny w napięciach na poziomie istnienia czuwającego ${ }^{10}$. Siły życiowe przejawiają się w sferze faktów. Są nam dostępne dzięki

6 O. Spengler, Zmierzch Zachodu, Warszawa 2014, s. 268.

7 Por. A. Kołakowski, Spengler, s. 61.

8 O. Spengler, Zmierzch Zachodu, s. 268.

9 Por. A. Kołakowski, Spengler, s. 65.

10 Por. A. Kołakowski, Spengler, s. 72. 
przeżyciu, tęsknocie, wewnętrznemu odczuciu, fizjonomicznym symbolom, obrazom i kształtom. Nie można ich jednak ująć za pomocą prawd i rozumowań przyczynowo-skutkowych ${ }^{11}$.

$\mathrm{W}$ oparciu o te ustalenia Spengler rezygnuje $\mathrm{z}$ dominującego $\mathrm{w}$ filozofii dziejów pojęcia ludzkości, jako właściwego podmiotu historii ${ }^{12}$. Zamiast tego kreśli wizję dziejów będących historią kultur rozumianych w kategoriach żywych organizmów, które posiadają odrębne dusze. Losy każdej kultury są do siebie zbliżone, powtarzają te same elementy, w tej samej konfiguracji, jednak w odmiennej szacie. Fatalizm koncepcji Spenglera przejawia się w koniecznym obumarciu każdej z kultur, które nastąpi po okresie mniej więcej tysiąca lat żywotności ${ }^{13}$.

Spengler wyróżnia osiem kultur: babilońską, egipską, chińską, hinduską, meksykańską, antyczną, zachodnioeuropejską oraz rodzącą się dopiero kulturę rosyjską. Wszystkie one pozbawione są jakichkolwiek związków i nie przenikają się ze sobą. Poszczególne ich okresy, np. gotyku czy baroku, posiadają w innych swoje odpowiedniki - „homologony”. W historii świata działa mechanizm cyklicznych narodzin i śmierci kultur, przechodzących kolejne stadia rozwoju ${ }^{14}$.

Podstawą dla tak rozumianej kultury są zjawiska oraz wartości charakterystyczne dla istnienia nieprzytomnego. Jednak wraz ze stopniowym kształtowaniem młodej jeszcze kultury zaczynają pojawiać się napięcia między zjawiskami z poziomu istnienia bezwiednego i zjawiskami nowymi, powstającymi w tym procesie. W momencie szczytowego rozkwitu kultury obserwujemy równowagę pomiędzy elementami istnienia nieprzytomnego i przytomnego. Następnie, gdy w sposób konieczny coraz większą przewagę zaczynają uzyskiwać te ostatnie, kultura przechodzi w etap cywilizacji, zmierzający do upadku ${ }^{15}$.

11 Por. A. Kołakowski, Spengler, s. 73.

12 O odrzuceniu idei ludzkości jako podmiotu procesu dziejowego szerzej pisze: Z. Czarnecki, Kryzys optymizmu historycznego: studium przewodnich idei, w: W kregu pesymizmu historycznego, red. Z. Czarnecki, Lublin 1992, s. 22n.

13 Por. Z. Kuderowicz, Filozofia dziejów, s. 223.

14 Por. A. Kołakowski, Spengler, s. 58.

15 Por. A. Kołakowski, Spengler, s. 66; O. Spengler, Zmierzch Zachodu, s. 43. 
Okres kultury stoi w opozycji do cywilizacji ${ }^{16}$. Charakterystyczne dla niego jest państwo chłopstwa i szlachty, podczas gdy cywilizację cechuje przewaga mieszczaństwa i duchowieństwa ${ }^{17}$. W pierwszej dominuje zamek i wieś, w drugiej rynek i tłum. Kultura jest aintelektualna, rytm jej życia wyznacza obyczaj. Moralność oparta na abstrakcyjnych pojęciach to element cywilizacji. Kulturę interesuje fakt, cywilizację prawda.

W okresie cywilizacji dochodzi do petryfikacji form właściwych życiu. Tracą one pierwotną żywiołowość i przybierają zewnętrzną, sztuczną formę. O ile okres kultury jest czasem stawania się, o tyle cywilizacja jest tym, co się stało. Statyczną formą, którą cechuje duchowa zgrzybiałość i kamienny świat miejskich murów. Jej najdobitniejszym symbolem jest metropolia - światowe miasto, „punkt, w którym skupia się całe życie szerszych regionów, podczas gdy reszta usycha" ${ }^{18}$.

Metropolia jest siedliskiem społeczeństwa kapitalistycznego i mieszczańskiego stanu czwartego. Omawiany autor określa ową masę jako "koniec" i „radykalną nicość"19. Jest ona zatomizowana i nie cechują jej więzi charakterystyczne dla życia, lecz abstrakcyjne pojęcie pieniądza. Przejawami tego agonalnego stadium cywilizacji jest wiodąca rola stanu czwartego w kreacji form życia politycznego. Następuje triumf parlamentaryzmu, demokracji i liberalizmu. Pojawiające się partie polityczne wypierają organiczne stany. Dominuje partykularyzm, prywatyzacja historii, wojny, polityki, aż po chęć prywatnego posiadania świata. W konsekwencji ostatnią formą rządów owych masowych społeczeństw staje się cezaryzm, rozumiany jako silna władza jednostki kierującej ową bezkształtną materią społeczną ${ }^{20}$.

16 Przeciwstawienie kultury i cywilizacji nie jest oryginalnym pomysłem Spenglera, lecz wywodzi się z poglądów niemieckiego socjologa Ferdynanda Tönniesa, który rozróżniał wspólnoty, społeczeństwa i zbiorowości. Zasługą Spenglera jest uzupełnienie tej myśli społecznej o wątki z filozofii Friedricha Nietzschego. Por. Z. Kuderowicz, Filozofia dziejów, s. 224.

17 Por. A. Kołakowski, Spengler, s. 76.

18 O. Spengler, Zmierzch Zachodu, s. 44.

19 A. Kołakowski, Spengler, s. 93

20 Zob. O. Spengler, Zmierzch Zachodu, s. 47n. 
Równolegle do imperializmu pojawia się inny wytwór cywilizacyjny socjalizm. Spengler rozróżnia dwa typy socjalizmu. Pierwszym jest socjalizm marksistowski, z którego idei wyrasta ruch robotniczy. W oczach autora Zmierzchu Zachodu model ten stanowi zaledwie szkielet, martwą mechaniczną zasadę docelowego postępu. Wiąże się on z działaniami owej bezkształtnej masy zamieszkującej miasta-molochy. Drugą postacią socjalizmu jest „etyczny socjalizm”, który nie daje się utożsamić $\mathrm{z}$ „systemem litości, humanitaryzmu, pokoju, opieki, lecz wolą mocy. (...) Jego cel jest imperialistyczny: dobrobyt w sensie ekspansywnym, nie dla chorych, lecz dla pełnych energii" ${ }^{21}$. Ten drugi typ socjalizmu ma być zrealizowany przez ożywione duchem pruskim społeczeństwo niemieckie, a ideałem i przyszłością jest Trzecia Rzesza ${ }^{22}$.

Reasumując, w koncepcji Spenglera dynamika dziejów ma charakter cykliczny. W swoim wywodzie nawiązuje on do modeli antycznych, osadzonych w schemacie narodzin, wzrostu i starości danego państwa. Nowością jest dokładny opis mechanizmu historii, który wyrasta ze źródeł filozofii życia. Cyrkularność tego modelu wiąże się również z pesymistycznym nastawieniem filozofa do ówczesnych zjawisk politycznych. Jak podkreśla Zdzisław Czarnecki, świadomość historii jako procesu cyklicznego zawsze wzmaga się w sytuacjach zwątpienia, gdy prognozowano rychłe załamanie się „tego systemu wartości, na którym wspiera się cała kultura europejska"23.

\section{Model liniowy}

U schyłku minionego stulecia Francis Fukuyama, autor głośnego Końca historii, przedstawił model dziejów oparty na linearnej koncepcji procesu historycznego. Jego myśl spotkała się jednocześnie z entuzjazmem, jak i falą krytyki ${ }^{24}$. Pisał bowiem, będąc pod silnym wrażeniem upadku

21 A. Kołakowski, Spengler, s. 96.

22 Por. A. Kołakowski, Spengler, s. 96.

23 Z. Czarnecki, Kryzys optymizmu historycznego: studium przewodnich idei, s. 7.

24 Por. I. Koepke, Francis Fukuyama i trzy dekady od „końca historii”, w: Filozofia przeszłości, filozofia przyszłości, red. J. Grygieńć, Toruń 2020, s. 41. 
ZSRR, zaś przyświecała mu wiara w potęgę demokracji liberalnej, której triumf uważał za finał procesu dziejowego. Jak twierdził: „Ogromna większość świata nie zna uniwersalnej ideologii, która dysponowałaby wystarczającą mocą, by rzucić wyzwanie liberalnej demokracji” ${ }^{25}$. Zatem koniec historii miałby polegać na zaniku „dalszego rozwoju podstawowych zasad oraz społecznych instytucji”, ponieważ to właśnie w demokracji liberalnej znajdą swoje ostateczne rozwiązanie wszystkie istotne problemy ${ }^{26}$.

Filozofia Fukuyamy wyrasta z interpretacji myśli Hegla przedstawionej przez Alexandre’a Kojève’a. W tym też kluczu buduje on narrację osnutą wokół koncepcji końca historii i zasady będącej jednocześnie esencją dziejów i ich motorem.

Idąc za Heglem, Fukuyama twierdzi, że proces historyczny jest postępowym ruchem zmierzającym do wyniesienia człowieka na coraz to wyższe poziomy racjonalności i wolności ${ }^{27}$. Proces ten nie będzie biegł w nieskończoność, lecz osiągnie swój kres wraz z rozwinięciem absolutnej samowiedzy. Na gruncie społecznym stan ten znajduje odzwierciedlenie w wolnym społeczeństwie, którego wyrazem jest właśnie demokracja liberalna. Nietrudno zauważyć zbieżność myśli Fukuyamy z doktryną Hegla. Według tego ostatniego proces historyczny wyznaczają dialektyczne zmiany, w myśl których każda forma zrzeszenia społecznego z czasem generuje swoje wewnętrzne sprzeczności. W efekcie dialektycznych przemian powstaje konkurencyjny model rzeczywistości społecznej, wolny od tychże wad. Z czasem zastępuje on poprzedni, lecz sam również będąc obarczony własnymi sprzecznościami, ostatecznie ustępuje miejsca kolejnemu, który też podzieli los poprzednich. Proces ten zakończy się wraz z krystalizacją takiego modelu, którego wewnętrzne sprzeczności nie będą mogły zrodzić nowego. Myśl tę Fukuyama oddaje stwierdzeniem: „Nie ma doskonalszych od liberalnych

25 F. Fukuyama, Koniec historii, Kraków 2009, s. 82.

26 Zob. F. Fukuyama, Koniec historii, s. 11.

27 Zagadnienie politycznego znaczenia filozofii dziejów Hegla doczekało się wnikliwego omówienia w polskiej literaturze przedmiotu: M.N. Jakubowski, Historiozofia jako filozofia praktyczna. Hegel a polska filozofia czynu, Bydgoszcz 1991. 
form organizacji społecznej i politycznej. Innymi słowy, liberalne społeczeństwa są wolne od «sprzeczności» wewnętrznych charakteryzujących wcześniejsze formy, dlatego doprowadzą dialektykę historyczną do jej punktu krańcowego"28.

Teza o linearności procesu historycznego nie ogranicza się jednak do wskazania końca historii. Wszak koniec historii może być również wykreowany na gruncie teorii cyrkularnej. Tym, co decyduje o zakwalifikowaniu danego modelu jako linearnego, jest nieodwracalność i niepowtarzalność wydarzeń historycznych.

Fukuyama czyni zadość powyższemu warunkowi, interpretując postęp jako kumulatywne zdobywanie ludzkiej wiedzy i stopniowe opanowywanie natury ${ }^{29}$. Przełomowe $w$ tym procesie okazują się powstanie metody naukowej i osiągnięcia nowożytnego przyrodoznawstwa. To właśnie dzięki nim możemy mówić o kumulatywnym i nieodwracalnym postępie. Jednocześnie postęp ten zrywa z cyklicznością poprzez dostarczenie historiozofii kierunkowego mechanizmu wyjaśnienia wielu aspektów dziejów ${ }^{30}$.

Jednak tak rozumiany postęp nie może stanowić samodzielnego argumentu na rzecz tezy o finale procesu dziejowego, czyli o końcu historii. Postęp bowiem sam z siebie nie zakłada żadnego ograniczenia. Można wszak pomyśleć historię jako nieskończony ruch ku coraz większemu poznaniu i opanowaniu przyrody, co wyklucza możliwość mówienia o końcu historii. Ponadto oparcie historiozofii na idei postępu naukowego spłyca samo znaczenie dziejów. Wykreowana w ten sposób historia będzie historią wynalazków i niekończącą się rozgrywką w starciu człowieka $\mathrm{z}$ naturą. Brakuje w niej miejsca na historię polityczną, historię rozwoju samoświadomości i wolności; brakuje miejsca na rozwój ducha.

Bardzo dobrze rozumiał to Hegel, który odmówił idei postępu naukowego miana mechanizmu dziejowego ${ }^{31}$. Stąd też Fukuyama, chcąc

\footnotetext{
28 F. Fukuyama, Koniec historii, s. 106.

${ }^{29}$ Zob. F. Fukuyama, Koniec historii, s. 95-97.

30 Zob. F. Fukuyama, Koniec historii, s. 118-119.

31 Zob. F. Fukuyama, Koniec historii, s. 206.
} 
być wiernym swojemu mistrzowi, wskazuje na jeszcze jeden czynnik procesu historycznego, a mianowicie pragnienie uznania. Rozważania wokół tego właśnie elementu systemu Hegla stanowią filozoficzną bazę dla kreowanej przez Fukuyamę filozofii dziejów. Jego istotność ujawniają dwie kwestie. Po pierwsze, rzuca on więcej światła na dziejowe zmienne, których nie można wyjaśnić poprzez rozwój przyrodoznawstwa. Po drugie, odpowiada na pytanie, czy historia będzie trwała wiecznie (wraz z postępem), czy też osiągnie swój kres.

Aby lepiej przedstawić to zagadnienie, musimy odwołać się do problematyki duszy ludzkiej. Już u Platona na duszę składały się trzy elementy: rozum, pożądanie i coś, co w grece określane jest jako thymos. Najczęściej thymos tłumaczono jako dzielność, jednak przekład ten nie oddaje semantycznej głębi terminu. Wydaje się, że spośród różnych interpretacji, w kontekście nas interesującym, na pierwsze miejsce wybija się postrzeganie thymos jako chęci bycia uznanym przez innych, potwierdzenie własnej wartości w oczach drugiego człowieka lub wspólnoty. To właśnie thymos leży u podstaw wszelkiej historii. Według Hegla proces dziejowy rozpoczął się krwawym bojem pomiędzy ludźmi, $\mathrm{u}$ których dominującą pozycję $\mathrm{w}$ duszy odgrywał właśnie thymos ${ }^{32}$. Pierwszy człowiek zażądał uznania od innych poprzez wyzwanie, które wiązało się z ryzykiem utraty własnego życia. Wskutek tego wyzwania ludzie podzielili się na tych, którzy dla potwierdzenia swej dominacji zaryzykowali życie, i tych, którzy nie podejmując wyzwania, zachowali bezpieczeństwo, ale kosztem rezygnacji z walki. Podział ten znalazł odzwierciedlenie w powstaniu grupy panów i grupy niewolników. Jednak nawet u tych ostatnich pierwiastek tymotejski nie wygasł, chociaż został pogrzebany pod potrzebami generowanymi przez aspekt pożądliwy duszy. Z kolei na ową pożądliwość składają się wartości związane z chęcią zachowania życia i gromadzenia dóbr materialnych. Ich realizacja przybiera postać dostatniego, wolnego od konfliktów i napięć życia. Jednak dziejowa rola thymos nie skończyła się wraz z okrzepnięciem podziału

\footnotetext{
32 Temat wojny często powraca w filozofii Hegla. Niemiecki filozof widzi w niej remedium na zastój i degenerację społeczną. M. N. Jakubowski, Historiozofia jako filozofia praktyczna, s. 81n.
} 
na panów i niewolników. Potrzeba uznania stoi właściwie za każdym kryzysem, konfliktem czy rewolucją. Tym samym stanowi właściwy mechanizm procesu dziejowego ${ }^{33}$.

W oparciu o powyższe ustalenia rysuje się przed nami obraz historii jako proces dualistyczny. $Z$ jednej strony mamy rozwój przyrodoznawstwa, który powoduje nieodwracalność procesu dziejowego, wyznacza kierunek historii i zapewnia zaspokojenie pożądliwej części duszy, charakterystycznej dla niewolnika ${ }^{34}$. Z drugiej, tymotejskie pragnienia jednostek i narodów, których stopień zaspokojenia odzwierciedla się w odporności na wewnętrzne sprzeczności danych instytucji i tworów społecznych $^{35}$. Innymi słowy, główną przyczyną powstawania wewnętrznych sprzeczności, które powodują upadek danego systemu społeczno-politycznego, jest niedostatek w zaspokojeniu potrzeby uznania.

W związku z powyższym pytaniu o koniec historii można nadać następujące brzmienie: Czy demokracja liberalna zawiera niedające się przezwyciężyć wewnętrzne sprzeczności? Kryje się w tym założenie, że skoro „społeczeństwa ludzkie z upływem wieków ewoluują ku jednej formie organizacji społeczno-politycznej, a mianowicie ku demokracji liberalnej, jeżeli nie wydaje się, aby istniały funkcjonalne alternatywy dla tej formy ustrojowej oraz jeżeli ludzie żyjący w demokracjach liberalnych nie wyrażają zasadniczego niezadowolenia ze swego życia, to możemy powiedzieć, że dialog został ostatecznie i definitywnie rozstrzygnięty" ${ }^{36}$.

Idąc za myślą komentatora Hegla - Alexandre’a Kojève’a, Fukuyama konstruuje model hegemonicznego państwa uniwersalnego, będącego zwieńczeniem dziejów ${ }^{37}$. Proces historyczny prowadzący do wykreowania tej formy organizacyjnej napędzany jest zarówno logiką nowożytnego przyrodoznawstwa, jak i walką o uznanie. Ta pierwsza siła wypływa z elementów pożądliwych i rozumnych w duszy ludzkiej, a obecnie realizuje się w nieograniczonej możliwości akumulacji bogactwa. Druga z kolei

\footnotetext{
33 Zob. F. Fukuyama, Koniec historii i ostatni człowiek, Kraków 2017, s. 387.

34 Zob. F. Fukuyama, Koniec historii i ostatni człowiek, s. 490.

35 Zob. F. Fukuyama, Koniec historii, s. 207.

36 F. Fukuyama, Koniec historii, s. 208.

37 Zob. F. Fukuyama, Koniec historii, s. 304.
} 
miałaby zostać zaspokojona poprzez warunki, jakie stwarza kultura liberalna.

Początkowy entuzjazm proroctwa końca dziejów z biegiem czasu uległ zachwianiu. Historia, jak się okazało, pomimo upadku Związku Radzieckiego wcale nie zwolniła swojego biegu. Duch tymotejski nie zanikł, nie zaspokoił się osiągnięciami liberalnego społeczeństwa. Wręcz przeciwnie, co i rusz dawał o sobie znać kolejnymi konfliktami. Okoliczności te zmusiły Fukuyamę do rozwinięcia swojej refleksji, co też uczynił w pracy Ostatni człowiek.

Zawarty tam wywód otwiera katalog czynników stanowiących przeszkody w rozprzestrzenianiu się demokracji liberalnej. Punktem odniesienia jest tutaj model państwa, które pragnie „ujednolicić zróżnicowane tradycyjne kultury i nauczyć naród rachowania swych dalekosiężnych korzyści”. Społeczeństwo to, w odróżnieniu od organicznej wspólnoty moralnej, będzie się skupiało wokół wartości demokratycznych, takich jak: partycypacja, racjonalność, laickość, mobilność, empatia i toleran$\mathrm{cja}^{38}$. Na drodze do realizacji tej formy społeczno-politycznej stoją zjawiska trojakiego rodzaju. Pierwsze z nich dotyczy charakteru i zakresu świadomości narodowej, etnicznej i rasowej w danej kulturze ${ }^{39}$. Drugą przeszkodę stanowi religia, o ile nie wyrzeknie się ona nietolerancji względem innych kultów oraz idei egalitaryzmu ${ }^{40}$. Wreszcie trzecim hamulcem rozkwitu demokracji liberalnej jest zdolność ludności do samodzielnego wytworzenia społeczeństwa obywatelskiego ${ }^{41}$.

Czynniki te sprawiają, że w niedalekiej przyszłości będą egzystowały obok siebie dwa światy: świat pohistoryczny i ten, który ciągle pozostanie zanurzony w historii ${ }^{42}$. Fukuyama tak oto charakteryzuje te dwa

38 Zob. F. Fukuyama, Koniec historii i ostatni człowiek, s. 331.

39 Zob. F. Fukuyama, Koniec historii i ostatni człowiek, s. 333.

40 Zob. F. Fukuyama, Koniec historii i ostatni człowiek, s. 334.

41 Zob. F. Fukuyama, Koniec historii i ostatni człowiek, s. 336.

42 Chociaż te dwa światy będą żyły oddzielnie, to jednak nie w zupełnej separacji. Istnieją bowiem dziedziny, w których losy państw historycznych będą się zazębiać z interesami krajów pohistorycznych. Fukuyama wymienia trzy takie obszary. Po pierwsze będzie to dostęp do ropy naftowej. Po drugie imigracja ze świata historycznego do pohistorycznego. Wreszcie, po trzecie, punkt styku będą stanowiły kwestie „porządku światowego”, rozumiane jako sprawy związane z przepływem 
światy: „W świecie pohistorycznym stosunki międzypaństwowe będą się obracać wokół spraw gospodarczych, a dawne reguły zostaną stopniowo zarzucone. (...) W świecie pohistorycznym nadal występowałyby państwa narodowe, lecz poszczególne nacjonalizmy żyłyby w zgodzie z liberalizmem i wyrażałyby się prawie wyłącznie w sferze życia prywatnego. Tymczasem racjonalność gospodarcza, poprzez dążenia do ujednolicenia rynku i produkcji, nadwątliłaby wiele tradycyjnych elementów suwerenności” "33. „Z kolei świat historyczny będzie wciąż trawiony rozmaitymi konfliktami religijnymi, narodowymi i ideologicznymi, o natężeniu zależnym od stopnia rozwoju poszczególnych krajów, w których wciąż stosowane będą dawne zasady polityki siły" ${ }^{44}$.

W tak spolaryzowanym świecie ostateczny i globalny triumf demokracji liberalnej można wieszczyć tylko przy jednoczesnym uznaniu jej za ostatni możliwy system. Rodzi się zatem pytanie o trwałość demokracji. „Czy w przypadku, gdyby demokracje liberalne zdominowały świat, to czy byłyby bytami trwałymi, czy może zrodzi się w przyszłości jakieś dla nich zagrożenie?"45 - pyta Fukuyama. Jednocześnie kieruje nas to do poruszonej już w Końcu historii kwestii możliwości zaspokojenia potrzeb związanych z troistą naturą duszy, co w konsekwencji będzie miało przełożenie na występowanie i wagę wewnętrznych sprzeczności ${ }^{46}$.

Aby jednak udzielić wyjaśnienia w tej kwestii, potrzebujemy kryteriów ponadhistorycznych; takich, które pozwolą ocenić społeczeństwo demokratyczne. Potrzebne jest pojęcia człowieka jako takiego, dzięki któremu ukażą się ewentualne wady systemu demokratycznego ${ }^{47}$. W myśl tezy Kojève’a tym, co decyduje o procesie historycznym, jest walka o uznanie. Stąd też koniec historii warunkowany jest zaspokojeniem

technologii (w szczególności wojennej) czy ochrony środowiska naturalnego. Zob. F. Fukuyama, Koniec historii i ostatni człowiek, s. 417-419.

${ }^{43}$ F. Fukuyama, Koniec historii i ostatni człowiek, s. 416.

44 F. Fukuyama, Koniec historii i ostatni człowiek, s. 417.

45 F. Fukuyama, Koniec historii i ostatni człowiek, s. 430.

46 Zob. F. Fukuyama, Koniec historii i ostatni człowiek, s. 430.

47 Zob. F. Fukuyama, Koniec historii i ostatni człowiek, s. 430. 
owego pragnienia tymotejskiego ${ }^{48}$. Czy demokracja rzeczywiście stwarza możliwości rozwiązania tego problemu?

Stanowiska krytyczne względem demokracji wypływają z dwóch środowisk: lewicowych i prawicowych. Obydwa te sposoby myślenia dają odpowiedź przeczącą na postawione powyżej pytanie.

Lewica uważa, że potrzeba uznania nie jest powszechnie zaspokojona na skutek nierówności ekonomicznych, które wytwarza kapitalizm. Fukuyama replikuje, iż nierówności ekonomiczne między ludźmi w dużej mierze powodowane są czynnikami naturalnymi, takimi jak geny odpowiadające za indywidualne uzdolnienia i różnice w temperamencie ${ }^{49}$. W tym punkcie należy zauważyć, że chociaż sam autor Ostatniego człowieka wydaje się usatysfakcjonowany przytoczonym przez siebie argumentem, to jednak nie rozwiązuje on wcale kwestii nierówności, a co najwyżej próbuje wyjaśnić jej genezę.

Znacznie bardziej problematyczne stają się zarzuty kierowane w stronę demokracji ze strony środowisk prawicowych. Skupiają się one mianowicie wokół samego celu równego uznania dla wszystkich. Cel ten jest nieosiągalny ze względu na prosty fakt, że ludzie z natury nie są sobie równi. Ponadto liberalna mentalność promuje relatywizm w stosunku do wyznawanych wartości. Tak tedy ostatni człowiek, członek demokratycznego społeczeństwa, nie dąży do uznania siebie za lepszego, lecz za nie gorszego od innych. Zaś wierność wartościom wynikającym z określonego światopoglądu zostanie zastąpiona przez niebudzącą większych kontrowersji troskę o zdrowie. W ten sposób nastąpi triumf niewolnika nad tymotejskim panem, a w konsekwencji obietnica zaspokojenia wszystkich aspektów duszy nigdy nie zostanie zrealizowana ${ }^{50}$. Demokracja zatem będzie dążyła do tworzenia ludzi słabych i pozbawionych aspiracji twórczych, przy jednoczesnym temperowaniu thymos jednostek bardziej ambitnych. Jednak z czasem, zepchnięta na dalszy plan

48 Zob. F. Fukuyama, Koniec historii i ostatni człowiek, s. 431.

49 Zob. F. Fukuyama, Koniec historii i ostatni człowiek, s. 432.

50 Zob. F. Fukuyama, Koniec historii i ostatni człowiek, s. 542. 
megalotymia, czyli potrzeba bycia uznanym za lepszego od innych, wydostanie się na powierzchnię, zagrażając trwaniu demokracji liberalnej.

W odpowiedzi na te zarzuty Fukuyama zwraca uwagę na pola ekspresji, gdzie owa megalotymia może znaleźć ujście w pokojowej formie, jednocześnie wpisując się w główne założenia społeczeństwa demokratycznego. Są nimi: działalność gospodarcza w przestrzeni wolnego rynku, rywalizacja na polu politycznym, praca naukowa, a nawet snobizm ${ }^{51}$.

Konkludując można powiedzieć, iż w filozofii dziejów Fukuyamy odnajdujemy elementy charakterystyczne dla klasycznej historiozofii. Motorem dziejów jest nowożytne przyrodoznawstwo oraz tymotejskie roszczenie uznania. Proces dziejowy w swej ostatecznej instancji wiedzie do kresu historii, hegemonicznego państwa uniwersalnego, rządzonego prawami demokracji liberalnej. Pomimo licznych potknięć, momentów zastoju, a nawet regresu, tak rozumiana historia nie zmieni swojego kierunku, gdyż „najdonioślejsze nawet zdarzenia same w sobie nie decydują o sensie dobiegającego końca historycznego procesu. Istotę jego wyznacza bowiem właściwa historia - jednolinearny, spójny, ewolucyjny ciąg zmian ukierunkowanych, na który składają się zbiorowe doświadczenia ludów wszystkich czasów"52. Stąd też ewentualne elementy cyrkularne i nieciągłości dają się przyrównać do swoich odpowiedników w biznesie, które jednak nie wpływają ostatecznie na długofalowy wzrost ekonomiczny ${ }^{53}$.

\section{Wnioski końcowe}

Chociaż cel niniejszego opracowania był raczej minimalistyczny chodziło mianowicie o prezentację dwóch modeli historiozoficznych: liniowego i cyrkularnego, w formie jaką nadała im filozofia XX wieku to jednak w podsumowaniu można pokusić się o kilka uwag, które wnoszą do powyższych rozważań wartość dodaną.

\footnotetext{
51 Zob. F. Fukuyama, Koniec historii i ostatni człowiek, s. 467.

52 F. Fukuyama, Koniec historii, s. 10.

53 Zob. F. Fukuyama, Koniec historii, s. 88.
} 
Zarówno Spengler, jak i Fukuyama mogliby się zgodzić, że proces historyczny wieńczą formy polityczne właściwe dla cywilizacji mieszczańskiej: demokracja, parlamentaryzm i liberalizm. Zgoda panuje również co do tego, że mechanizm historii w sposób nieunikniony zmierza ku wytworzeniu się imperialistycznego państwa, gdzie indywidualizm i kreatywność gospodarcza jednostki są w pewnej mierze równoważone przez silny element socjalny. Jakkolwiek przytoczeni myśliciele różnią się w ocenie tychże zjawisk. W dziele Spenglera powstałe u kresu procesu dziejowego społeczeństwo liberalne przedstawiane jest krytycznie. Niemiecki badacz postrzega jego wzrost jako okres petryfikacji form właściwych „życiu”, określa mianem „nicości”, degeneracją kultury. Z kolei w myśli Fukuyamy te same instytucje i formy politycznego życia są największym osiągnięciem cywilizacji zachodniej i stanowią jednocześnie wartość uniwersalną, ponad którą już nic lepszego w dziejach systemów społeczno-politycznych stworzyć nie można. Tym samym ich triumf jest przejściem do epoki pohistorycznej.

Wydaje się, że rozbieżności te są silnie powiązane z zakładaną koncepcją historiozoficzną. Niezależnie od tego, czy przyjęcie odpowiedniego modelu procesu historycznego (liniowego lub cyklicznego) spowodowało pozytywną czy negatywną interpretację rzeczonych form organizacji społeczno-politycznej, czy też ocena ta była uprzednia i znalazła swój wyraz w wyborze takiej, a nie innej interpretacji historii, widać wyraźnie, że założenia historiozoficzne pozostają w ścisłej łączności z afirmacją bądź krytyką historycznych modeli życia społeczno-politycznego.

Innymi słowy, Fukuyama nie mógł ogłosić końca historii i ostatecznego triumfu demokracji liberalnej bez jednoczesnego założenia liniowości dziejów. Z kolei Spengler nie mógł przeprowadzić krytyki miejskiego społeczeństwa kapitalistycznego, nie przewidując jednocześnie zmierzchu i upadku cywilizacji.

Będąc uczciwym, należy zauważyć, że możliwe są również katastroficzne ujęcia historiozoficzne na gruncie teorii liniowej dziejów, lecz wtedy nie ma mowy o postępie jako wewnętrznej zasadzie procesu historycznego. $Z$ drugiej strony również i pewien wariant modelu cyrkularnego dopuszcza optymistyczne prognozy, wedle których upadek 
danej kultury nie jest nieunikniony. Jednak taki pogląd implikuje stwierdzenie, iż istnieje możliwość przerwania cyklu. Zatem ani w pierwszym, ani $\mathrm{w}$ drugim przypadku nie mamy do czynienia $\mathrm{z}$ konsekwentnym przyjęciem danej teorii: cyrkularnej lub liniowej, w jej „czystej” postaci.

Powyższe rozważania prowokują również pytanie o rolę pojęcia kultury $\mathrm{w}$ historiozofii ${ }^{54}$. Pojawia się ono jako jedno z centralnych pojęć u Spenglera. Również w myśli Fukuyamy odgrywa pierwszorzędną rolę (pomimo, że sam autor Końca historii nie zdecydował się na przedstawienie własnej jego definicji). Chociaż pojęcie to pojawia się już w rozważaniach Vico i Woltera, to jednak waloru istotności nabiera dopiero dzięki pracom Emila Durkheima ${ }^{55}$.

Wydaje się, że wyeksponowanie kultury jako autonomicznego obiektu badań jest elementem, który charakteryzuje filozofię dziejów XX wieku i nadaje jej walor oryginalności w stosunku do historiozofii wcześniejszych epok. Dzięki pracom takich myślicieli, jak Nikołaj Danilewski, Oswald Spengler, Arnold J. Toynbee czy Władimir Sorokin, rozumienie kultury nabrało cech historiozoficznych i de facto określiło nowy podmiot historii. $\mathrm{O}$ ile $\mathrm{w}$ pracach starszych autorów historia jest przede wszystkim historią narodów, wybranej wspólnoty wiernych, państwa Bożego lub nawet całej ludzkości, o tyle w ostatnim wieku chętniej mówiono o historii kultur. Poszukiwano mechanizmów dziejowych, które charakteryzowałyby dzieje kultury. Stąd też narracja filozofii dziejów została osnuta właśnie wokół historii kultur: ich wzrostu i upadku, epok lub stadiów, przez które przechodzą, wagi przeszłości i perspektyw przyszłości.

54 Bez wątpienia pojęcie „kultura” odznacza się wielką elastycznością; w zależności od autora zmienia się jego zakres semantyczny. Szerzej o problemach związanych z definicją kultury oraz bogactwem znaczeń, jakie może ono przybierać traktują: A.L. Kroeber, C. Kluckhohn, Culture. A Critical Review of Concepts and Definitions, New York 1966; C. Geertz, The Interpretation of Culture, New York 1973.

55 Durkheim ściśle łączy kulturę ze społeczeństwem, nierzadko nawet przydając tej pierwszej rolę wtórną względem drugiego. Zależność ta jest na tyle ścisła, że teoretyk chcący badać społeczeństwo, musi w pierwszej kolejności skupić swoją uwagę właśnie na jego wytworach, czyli kulturze. Zob. E. Durkheim, Elementarne formy życia religijnego, Warszawa 1990. 
Powyższego spostrzeżenia nie należy jednak uważać za tezę udowodnioną na gruncie niniejszego opracowania. Jest to raczej zagadnienie, pytanie, myśl otwierająca pewien horyzont badań nad filozofią dziejów.

\section{Bibliografia}

Angehrn E., Filozofia dziejów, tłum. J. Marzęcki, Kęty 2007.

Czarnecki Z.J., Kryzys optymizmu historycznego: studium przewodnich idei, w: W kregu pesymizmu historycznego, red. Z.J. Czarnecki, Lublin 1992, s. 5-41.

Czarnecki Z.J., Przyszłość i historia, Lublin 1981.

Czarnecki Z.J., Wartość i historia. Studia nad refleksją filozoficzną o ludzkim świecie, Lublin 1992.

Durkheim E., Elementarne formy życia religijnego, tłum. A. Zadrożyńska, Warszawa 1990.

Edelstein L., The Idea of Progress in Classical Antiquity, Baltimore 1967.

Eliade M., Mit wiecznego powrotu, tłum. K. Kocjan, Warszawa 1998.

Fukuyama F., Koniec historii, tłum. T. Bieroń, M. Wichrowski, Kraków 2009.

Fukuyama F., Koniec historii i ostatni człowiek, tłum. T. Bieroń, M. Wichrowski, Kraków 2017.

Geertz C., The Interpretation of Culture, New York 1973.

Jakubowski M.N., Historiozofia jako filozofia praktyczna. Hegel a polska filozofia czynu, Bydgoszcz 1991.

Koepke I., Francis Fukuyama i trzy dekady od „końca historii”, w: Filozofia przeszłości, filozofia przyszłości, red. J. Grygieńć, Torun 2020, s. 41-71.

Kołakowski A., Spengler, Warszawa 1981.

Kroeber A.L., Kluckhohn C., Culture. A Critical Review of Concepts and Definitions, New York 1966.

Lloyd G.E.R., Czas w myśli greckiej, w: Czas w kulturze (207-261), red. A. Zajączkowski, Warszawa 1988, s. 207-261.

Nisbet R., History of The Idea of Progress, New York 1980.

Nisbet R., Social Change and History. Aspects of Western Theory of Development, New York 1969.

Sklair L., The Sociology of Progress, London 1970. 
Spengler O., Der Untergang des Abendlandes, München 1922.

Spengler O., Zmierzch Zachodu, tłum. J. Marzęcki, Warszawa 2014.

\section{Abstrakt \\ Cykliczny i linearny obraz dziejów w historiozofii XX wieku na podstawie myśli Oswalda Spenglera i Francisa Fukuyamy}

W niniejszym artykule zaprezentowane zostały dwa modele historiozoficzne, obecne w filozofii dziejów XX wieku. Pierwszy, zakładający cykliczność dziejów, ukazany został na podstawie dzieła Oswalda Spenglera Zmierz Zachodu. Drugi z kolei, linearny, stanowił założenie filozofii dziejów zawartej w Końcu historii i Ostatnim człowieku Francisa Fukuyamy. W tym kontekście poruszone zostały kwestie postępu i regresu, nieodwracalności procesu historycznego oraz determinizmu dziejowego. W podsumowaniu autor zwraca uwagę na to, w jaki sposób wybór określonej koncepcji dziejów: linearnej lub cyklicznej, koresponduje z krytyką bądź afirmacją zastanego porządku społeczno-politycznego. Jednocześnie zostaje postawione pytanie o znaczenie pojęcia „kultury”, jako charakterystycznego dla historiozofii XX wieku podmiotu dziejów.

\section{Słowa kluczowe}

filozofia dziejów, historiozofia, linearność, cykliczność, kultura

\section{Abstract}

\section{A Cyclical and Linear Picture of History in the Historiosophy of the $20^{\text {th }}$ Century Based on the Ideas of Oswald Spegler and Francis Fukuyama}

This article presents two historiosophical models present in the philosophy of history in $20^{\text {th }}$ century. The first one, assuming the cyclical nature of history, was presented on the basis of Oswald Spengler's The Decline of the West. The second, linear, was the foundation of the philosophy of history contained in The End of History and the Last Man by Francis Fukuyama. In this context, issues of progress and regression, the irreversibility of the historical process as well as historical determinism were raised. In the summary, the Author 
draws attention to the way in which the choice of a specific concept of history: linear or cyclical, corresponds with the criticism or affirmation of the existing socio-political order. At the same time, the question is raised concerning the meaning of the term "culture" as the subject of history characteristic of the historiosophy of the twentieth century.

\section{Keywords}

philosophy of history, historiosophy, linearity, cyclicality, culture 